\title{
The Demographic and Behavior Determinant of Credit Card Default in Indonesia
}

\author{
Wahid Achsan ${ }^{1 *}$, Noer Azam Achsani ${ }^{2}$, Bayu Bandono ${ }^{3}$ \\ 1, 2, 3School of Business, IPB University, Bogor, Indonesia \\ E-mail: ${ }^{1}$ achsanwahid@gmail.com, ${ }^{2}$ achsani@yahoo.com, ${ }^{3}$ bayu_b57@yahoo.com
}

*Corresponding author

JEL Classification:

$\mathrm{C} 38$

D10

G21

G40

Received: 27 March 2021

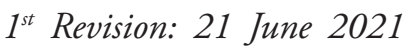

$2^{\text {nd }}$ Revision: 30 June 2021

Accepted: 12 July 2021

\begin{abstract}
The purpose of this paper is to analyze the demographic and behavioral factors that significantly affect the credit card NonPerforming Loan (NPL). This study is carried out to provide managerial recommendations for controlling credit card NPL. This study uses secondary data from Indonesia's most significant private bank with 100,000 samples of cardholder data. Demographic factors and cardholder behavior that significantly influence credit card NPL can be used to improve the credit scoring system for new cardholders and as indicators for a behavior scoring system for existing cardholders. This research uses a probability stratified random sampling technique. Logistic regression uses demographic factors and cardholder behavior significantly affected credit card NPL. According to the logistic regression model, cardholder behavior was more likely to NPL than demographic characteristics. The number of credit cards showed the highest credit card NPL probability.
\end{abstract}

\section{Keywords:}

credit card, behavior, demographic, logistic regression model, nonperforming loan

How to Cite:

Achsan, Wahid, Achsani, N. A, \& Bandono, Bayu. (2022). The Demographic and Behavior Determinant of Credit Card Default in Indonesia. Signifikan: Jurnal Ilmu Ekonomi, 11(1), 43-56. https://doi.org/10.15408/sjie. v11i1.20215. 


\section{INTRODUCTION}

Indonesia is a developing country with the fourth largest population in the world (2,642 million in December 2018). Indonesia has a demographic bonus where the economic productive population is $68 \%$ of the total population. Indonesia will experience a demographic bonus up to 2045. Furthermore, in December 2018, household consumption was still the main pillar of national economic growth. The composition of household consumption in 2018 was 55.7\% of Gross Domestic Product (GDP). Household consumption expenditure in the fourth quarter of 2018 grew 5.08\% compared to 2017. Thus, the dominance of the productive age population will push household consumption even higher in the coming years. This condition strengthens Indonesia as a potential emerging market economy and a place for investment.

One of the prospective businesses in Indonesia is credit cards, as indicated by the number of credit cardholders, which is low compared to the productive age population in Indonesia (9,53\% in December 2018). In addition, the number of cards and credit card transaction values from 2014-2018 experienced growth (Figure 1). In 2019 there were 25 credit card issuers, consisting of banks and non-bank financial institutions (Central Bank of Indonesia, 2019). The number of credit card issuers has increased compared to 2005 (17 issuers).

Figure 1. Number of Credit Card and Transaction Values

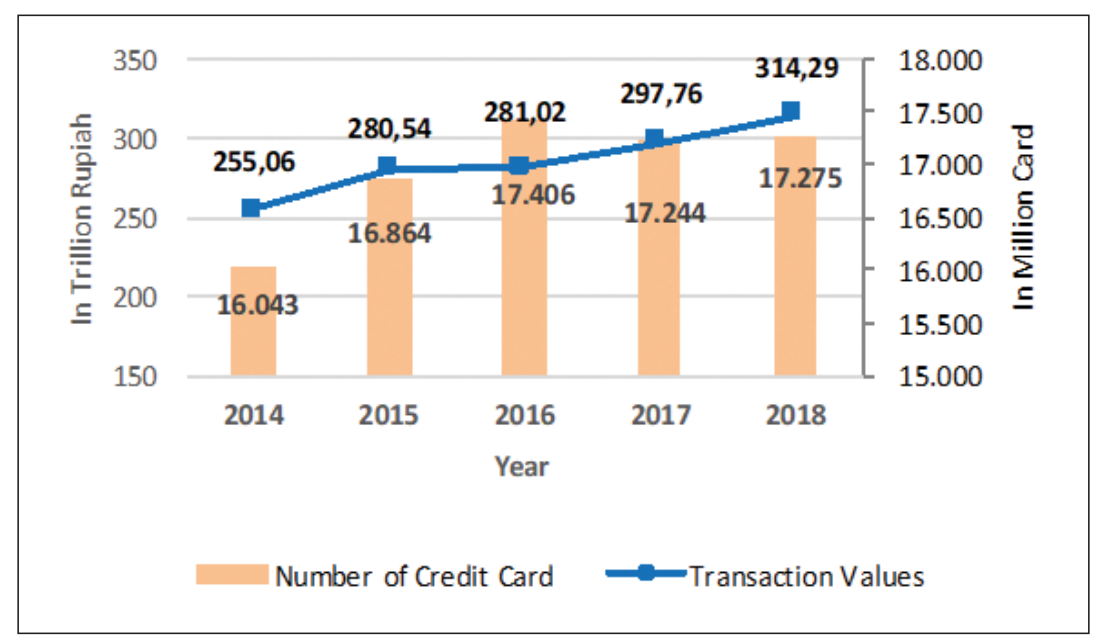

Credit cards make it easy for cardholders to make payments for purchases made. Cardholders do not need cash, and the credit card issuer makes payment transaction purchases first. Cardholders are obliged to pay off the issuer at the agreed time, either immediately or in installments. Credit cards also make it easy for cardholders to withdraw cash from an ATM (Automated Teller Machine). In addition, according to the Central Bank of Indonesia (BI) regulation No. 18/33/DKSP reduced the maximum limit on credit card interest rates from $2.95 \%$ to $2.25 \%$ per month since 2 December 2016. This will ease the burden on cardholders when bill payments are not made in full. Credit cards are unsecured consumer loans offered by banks (Wilson, 2007). This indicates the bank 
will have a greater percentage of losses than other types of credit if a borrower defaults. Therefore, growth of credit card business must be balanced with good credit quality.

According to Central Bank of Indonesia (BI) regulation No. 14/15/PBI/2012, bank credit quality is grouped into five areas, consisting of current $(\mathrm{L})$, special attention (DPK), substandard (KL), doubtful (D), and bad (M). Credit quality can be measured using a Non-Performing Loan (NPL), which is the ratio of outstanding loans that are substandard, doubtful, and bad to a total loan. Therefore, NPL can reflect credit default risk. According to the description above, it is important for banks to understand the factors that affect credit card NPL. By understanding the factors that influence the level of NPL, credit quality and bank soundness can be maintained, so that the growth of the credit card business can provide long-term benefits for banks.

Wang et al. (2011) showed that only three factors significantly influenced credit card quality (demographics, behavior, and cardholder personality). According to Agarwal et al. (2011), the factors that significantly influence credit card quality are marital status, homeownership, and urbanization. Furthermore, Bellotti and Crook (2013) showed that these three factors had a significant effect on the credit card quality of cardholders through variables of occupation, age, income, the number of credit cards, the ratio of payment to bills, transaction frequency, and credit limit. Kiarie (2015) showed that homeownership and age significantly affected credit card quality. In addition, Porto et al. (2017) showed that cardholders who live in rural areas have a greater probability of delaying payment/ not full payment than cardholders who live in urban areas. Li et al. (2019) studied factors that affect the quality of credit cardholders by using demographics and cardholder behavior. The results showed that factors that significantly influenced the credit quality of cardholders were gender, age, marital status, type of transaction, transaction frequency, and nominal per transaction. One study on factors affecting credit card defaults in Indonesia has been conducted by Sayono et al. (2009) and showed variables like gender, marital status, and income increased the probability of credit card defaults.

Table 1. Growth of Card Number, Transaction Value, and Outstanding Credit Card (2014 - 2018)

\begin{tabular}{|c|c|c|c|c|c|c|}
\hline & \multicolumn{5}{|c|}{$\begin{array}{l}\text { Growth } \\
\text { (\%) }\end{array}$} & \multirow[t]{2}{*}{$\begin{array}{c}\text { Average } \\
(\%)\end{array}$} \\
\hline & 2014 & 2015 & 2016 & 2017 & 2018 & \\
\hline \multicolumn{7}{|c|}{ Number of Card } \\
\hline National & 6.31 & 5.11 & 3.22 & -0.93 & 0.18 & 2.78 \\
\hline Bank & 5.09 & 6.39 & 8.55 & 10.49 & 9.50 & 8.00 \\
\hline \multicolumn{7}{|c|}{ Transaction Value } \\
\hline National & 14.19 & 9.99 & 0.17 & 5.96 & 5.55 & 7.17 \\
\hline Bank & 17.90 & 9.76 & 6.13 & 13.41 & 14.45 & 12.33 \\
\hline \multicolumn{7}{|c|}{ Outstanding } \\
\hline National & 22.57 & 12.0 & 7.16 & 4.63 & 1.38 & 9.55 \\
\hline Bank & 18.35 & 8.10 & 13.71 & 6.96 & 11.80 & 11.78 \\
\hline
\end{tabular}


Some previous studies have been conducted to examine the factors that significantly affect the credit quality of credit cards. This study uses secondary data obtained from the biggest private bank in Indonesia with average card growth, transaction value, and outstanding credit cards above the national average (Table 1). Various diverse emerged, but several commonalities were found, such as the demography and behavior of cardholders. The difference between this study and previous studies lies in the variables, data collection, and analysis methods. This study uses a complete variable by combining demographics and cardholder behavior so that it is expected to get more comprehensive results.

Figure 2: NPL Credit Card and Total Credit Bank

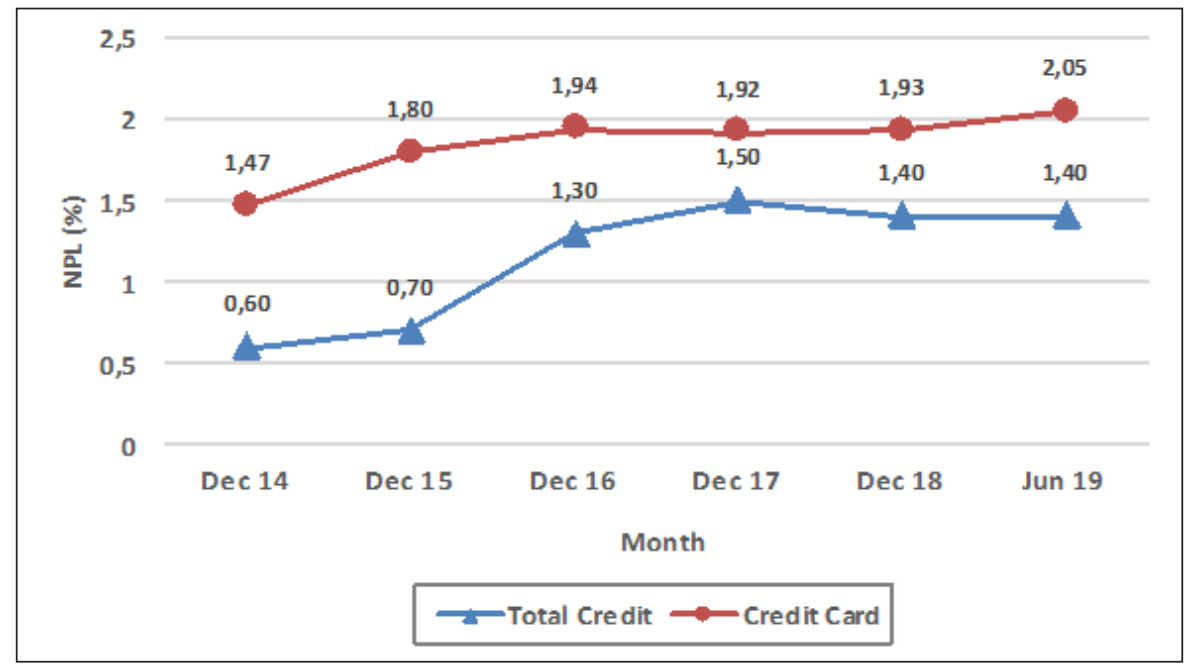

The purpose of this study is to analyze the demographic and behavioral factors that significantly affect the credit card Non-Performing Loan (NPL). Furthermore, from 2014 to June 2019, the trend of credit card NPL has increased and is always higher than the NPL of total credit banks (Figure 2). This study is carried out to provide managerial recommendations for controlling credit card NPL. Our results are also expected to enrich the existing literature on credit card products.

\section{METHODS}

Analyses of demographic factors and cardholder behavior were conducted by taking a sample of the cardholder data population as of June 2019. The sampling method used probability sampling with a stratified random sampling technique. The total sample used was 100,000 cardholders spread over each island in Indonesia. Variables were grouped into two categories that describe demographic factors and cardholder behavior. Types and definitions of variables are shown in Table 2.

This research is using logistic regression to determine demographic factors, social status, and cardholder behavior that significantly influenced cardholder NPL. Logistic Regression was chosen to examine the effect of independent variables on dependent variables that consists of two or more categories (Firdaus et. al., 2011). Press and Wilson 
(1978) state that the advantages of logistic regression is that it does not require the assumption of normality of the independent variable, meaning the independent variable must not have a normal distribution. Categorical independent variables tend not to be normally distributed (Halperin et al., 1971). Logistic regression can be used to analyze independent variables that are continuous, discrete, and dichotomous (Kuncoro, 2005). Firdaus et al. (2011) added that logistic regression is not required to fulfil the nonmulticolinearity and the size of each group does not have to be the same.

Table 2. Type and Definition Variables

\begin{tabular}{|c|c|c|c|}
\hline Factors & $\begin{array}{l}\text { Type of } \\
\text { Variables }\end{array}$ & Variables & Variables Definition \\
\hline Demographic & Independent & $\begin{array}{l}\text { - } \text { Age } \\
\text { - Gender } \\
\text { - Education } \\
\text { - Occupation } \\
\text { - Income } \\
\text { - Residential Area }\end{array}$ & $\begin{array}{l}\text { Year } \\
\text { Male; Female } \\
\text { Under/Graduate/Post; Non-Under/ } \\
\text { Graduate/Post } \\
\text { Self Employed; Non-Self Employed } \\
\leq 10 \text { million; > } 10 \text { million (Rupiah) } \\
\text { Java; Non-Java }\end{array}$ \\
\hline \multirow{3}{*}{ Behavior } & & $\begin{array}{l}\text { - } \text { Marital Status } \\
\text { - Home Ownership Status }\end{array}$ & $\begin{array}{l}\text { Married; Single/Widow/Widower } \\
\text { Own; Not Own }\end{array}$ \\
\hline & & $\begin{array}{l}\text { - } \text { Bill to Income Ratio } \\
\text { - } \text { Bill to Credit Limit Ratio } \\
\text { - } \text { Payment to Bill Ratio } \\
\text { - } \text { Credit Limit to Income } \\
\text { - } \text { Ratio } \\
\text { - } \quad \text { Number of Card } \\
\text { - Credit Limit }\end{array}$ & $\begin{array}{l}\text { Percent } \\
\text { Percent } \\
\text { Percent } \\
\text { Percent } \\
\text { Average per Month } \\
\text { Card } \\
<20 \text { Million; } \geq 20 \text { Million (Rupiah) }\end{array}$ \\
\hline & Dependent & Non-Performing Loan & NPL; Non-NPL \\
\hline
\end{tabular}

The logistic regression model for demographic factors, social status, and cardholder behavior that affect cardholder NPL was as follows:

$$
\text { Logit }\left(Y_{i}\right)=\propto+\beta_{1} X 1_{i}+\ldots+\beta_{n} X t_{i}+\varepsilon_{i}
$$

Where:

$$
\begin{aligned}
\mathrm{Y} & =\text { Independent Variable } \\
\mathrm{X} & =\text { Dependent Variable } \\
\propto & =\text { Constant } \\
\beta & =\text { Dependent Variable Coefficient } \\
\varepsilon & =\text { Error } \\
\mathrm{i} & =\text { Cardholder }
\end{aligned}
$$




\section{RESULT AND DISCUSSION}

The estimation results of the logistic regression model consist of 12 independent variables (Table 3). An omnibus test of model coefficient shows Chi square statistics with a significance level $\leq 0.05$, meaning there is a significant influence of the independent variables simultaneously on the dependent variable. A Nagelkerke $\mathrm{R}$ square of $65.5 \%$, meaning that the ability of independent variables to explain the dependent variable is $65.5 \%$. The percentage correct classification value is $98 \%$ and above Cpro (93.84\%), which shows that the model has good predictive accuracy.

The independent variable that partially affects the credit card NPL can be seen from the Wald Test results with a significance level $\leq 0.05$. Based on the Wald Test results, demographic factors that significantly affect the credit card NPL consist of age, gender, education, occupation, and residential area. Cardholder behavior factors that have a significant influence on credit card NPL are Payment to Bill (RP) Ratio, Ratio of Bill to Limit Credit (RL), Cash Advance Frequency (CA), Number of Credit Cards, and Credit Card Limit. Exp (B) of each variable on the cardholder behavior factor is greater than the demographic factor. This shows that cardholder behavior factors have a higher probability of influencing credit card NPL than demographic factors.

Table 3. Logistic Regression Estimation Result

\begin{tabular}{|c|c|c|c|c|}
\hline \multirow{2}{*}{ Variables } & \multirow{2}{*}{ Coefficient } & \multicolumn{2}{|c|}{ Wald Test } & \multirow{2}{*}{$\operatorname{Exp}(B)$} \\
\hline & & Values & Sig. & \\
\hline Gender (Male) & 0.383 & 54.837 & 0.000 & 1.466 \\
\hline $\begin{array}{l}\text { Marital Status (Single/Widow/ } \\
\text { Widower) }\end{array}$ & 0.016 & 0.065 & 0.798 & 1.016 \\
\hline Education (Non-Undergraduate) & 0.442 & 73.717 & 0.000 & 1.556 \\
\hline Occupation (Self Employed) & 0.269 & 18.472 & 0.000 & 1.309 \\
\hline Residential Area (Java) & 0.405 & 23.968 & 0.000 & 1.499 \\
\hline Income ( $\leq 10$ million) & -0.098 & 2.525 & 0.112 & 0.907 \\
\hline Credit Limit ( $\geq 20$ million) & -0.415 & 18.571 & 0.000 & 0.661 \\
\hline Age & -0.032 & 83.385 & 0.000 & 0.969 \\
\hline Number of Card & -4.879 & $3,471.649$ & 0.000 & 0.008 \\
\hline Payment to Bill Ratio & -4.233 & $1,148.232$ & 0.000 & 0.015 \\
\hline Cash Advance Frequency & -0.555 & 95.109 & 0.000 & 0.574 \\
\hline Bill to Credit Limit Ratio & 1.122 & 158.076 & 0.000 & 3.071 \\
\hline Constant & 5.656 & 593.204 & 0.000 & 285.951 \\
\hline \multicolumn{5}{|l|}{ Model Goodness Test } \\
\hline \multicolumn{5}{|c|}{ Omnibus Test of Model Coefficient (Chi-square Statistic = 1,7519.937; Sig. $=0.000$ ) } \\
\hline \multicolumn{5}{|l|}{ Nagelkerke R Square $=65.5 \%$} \\
\hline \multicolumn{5}{|c|}{ Percentage Correct Classification $=98 \% ;$ Cpro $=93.84 \%$} \\
\hline
\end{tabular}


Age has a negative coefficient, meaning that young cardholders tend to have a higher probability of NPL. This condition is in line with the results from Kim (2000), Stavins (2000), Muthomi (2005), Nyamongo (2011), Bellotti and Crook (2013), Wang et al. (2014), Kiarie et al. (2015), Huang (2018), Kim et al. (2018), and Li et al. (2019). Based on Figure 3, the percentage of the number of NPL cardholders compared to the total cardholders continues to increase with the younger age group. Conversely, the percentage of non-NPL cardholders continued to decline compared to total cardholders by age category.

Figure 3. Percentage of Non-NPL and NPL Cardholders by age category

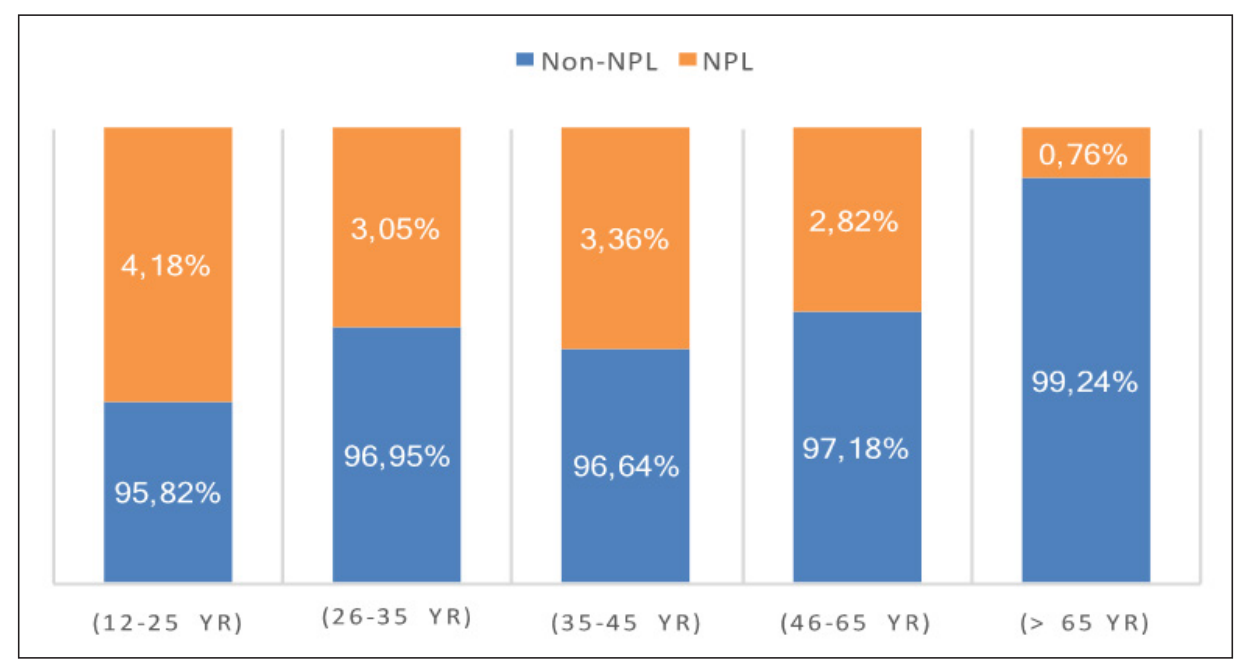

Figure 4 shows the relationship between age categories and cardholder income. The figure shows that the younger age category has a lower income than the older age category. Young cardholders have a higher probability of NPL because their cardholder income is still low, while the desire of young cardholders to try new things is very high.

Figure 4. Credit Limit and Income of Non-NPL and NPL Cardholders by Age Category

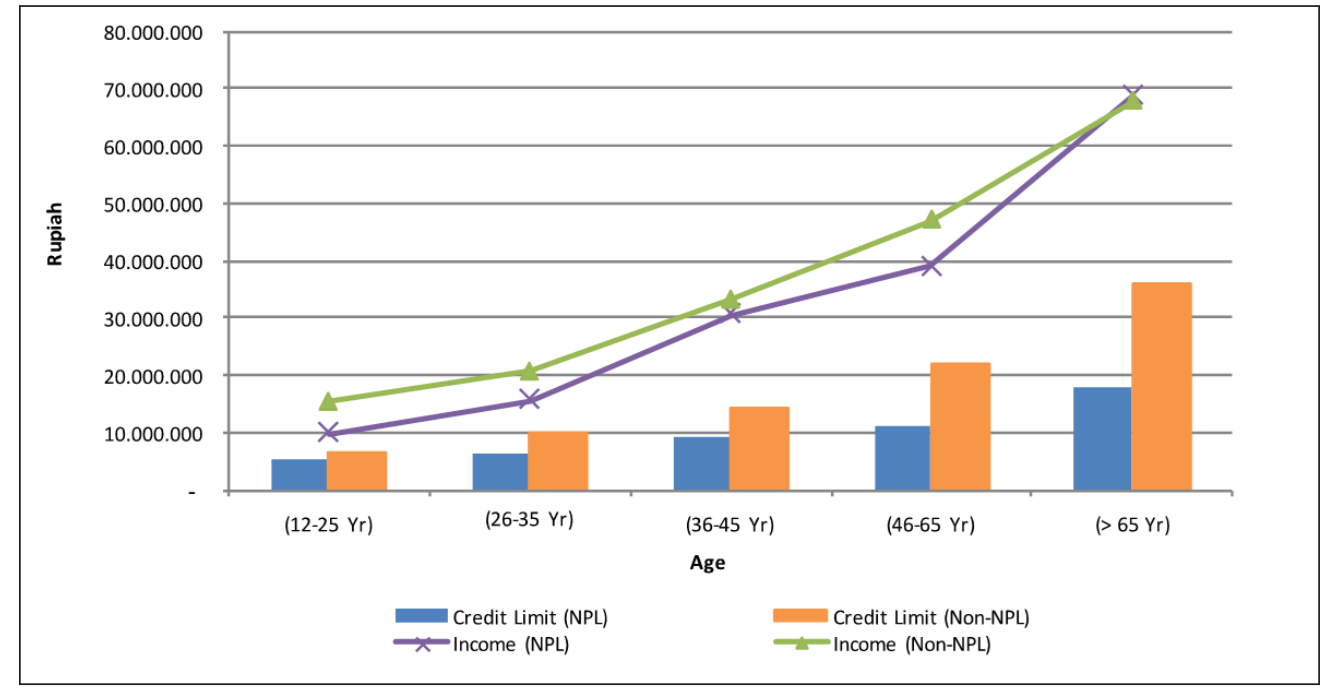


Male has a positive coefficient, so males tend to show a higher probability of NPL than females. This condition is in line with the results from Muhmin and Umar (2007), Muchiru (2008), Sayono (2009), Wang et al. (2014), Chin et al. (2017), Huang (2018), Kim et al. (2018), Li et al. (2019). Based on the sample, $60.09 \%$ of the NPL cardholders are male. Table 4 shows that the male NPL cardholders are not yet financially secure (61.29\% income $\leq 10$ million) and must provide family support (61.45\% are married). The level of education of most non/under/postgraduates (54.79\%) makes it difficult to pursue a career at a higher level $(70.30 \%$ of cardholders with non-self-employed). Cardholders mostly live in Java (90.52\%), especially in the regions of DKI Jakarta, West Java, and Banten, so they have a higher expenditure level than other regions.

Table 4. Characteristics of Male NPL Cardholders

\begin{tabular}{|c|c|c|}
\hline \multirow{2}{*}{ Male } & \multicolumn{2}{|l|}{ NPL } \\
\hline & Number of Cardholder & $\%$ \\
\hline \multicolumn{3}{|l|}{ Age } \\
\hline $12-25$ & 181 & 9,48 \\
\hline $26-35$ & 818 & 42.85 \\
\hline $36-45$ & 557 & 29.18 \\
\hline $46-65$ & 349 & 18.28 \\
\hline$>65$ & 4 & 0.21 \\
\hline \multicolumn{3}{|l|}{ Education } \\
\hline Under/Graduate/Post & 863 & 45.21 \\
\hline Non Under/Graduated/Post & 1,046 & 54.79 \\
\hline \multicolumn{3}{|l|}{ Occupation } \\
\hline Self Employed & 567 & 29.70 \\
\hline Non-Self Employed & 1,342 & 70.30 \\
\hline \multicolumn{3}{|l|}{ Income (Rupiah) } \\
\hline$\leq 10$ Million & 1,170 & 61.29 \\
\hline 3 - 5 Million & 713 & 60.94 \\
\hline > 5 - 10 Million & 457 & 39.06 \\
\hline > 10 Million & 739 & 38.71 \\
\hline \multicolumn{3}{|l|}{ Residential Area } \\
\hline Java & 1728 & 90.52 \\
\hline Non-Java & 181 & 9.48 \\
\hline \multicolumn{3}{|l|}{ Marital Status } \\
\hline Married & 1,173 & 61.45 \\
\hline Single/Widow/Widower & 736 & 38.55 \\
\hline \multicolumn{3}{|l|}{ Home Ownership Status } \\
\hline Own & 734 & 38.45 \\
\hline Not Own & 1,175 & 61.55 \\
\hline TOTAL & 1.909 & \\
\hline
\end{tabular}


Non-under/graduate/post education has a positive coefficient. This shows that cardholders with a non-under/graduate/post level of education have a higher probability of NPL than a cardholder with a level of under/graduate/post education. This condition is in line with the results of study by Stavins (2000), Norvilitis \& Maria (2002), Muhmin \& Umar (2007). Based on Table 5, non-under/graduate/post education NPL cardholder are mostly non-self-employed (70.44\%), married (59.92\%), living in Java (92.72\%), and do not yet have their own home $(64.81 \%)$. The level of non-under/graduate/post education makes it difficult for cardholders with non-self-employed status to pursue a career at a higher level, give their married status, cost of living in Java, and not yet owning a home, which causes higher cardholder spending, while most of the income is between IDR 3-5 million $(68.02 \%$ of income $\leq 10$ million).

Self-employed status is a positive coefficient. This shows that self-employed individuals have a higher NPL probability than cardholders with non-self-employed status. This condition is in line with results from Muthomi (2005), Muchiru (2008), Bellotti and Crook (2013), Leow \& Crook (2014), and Warnakulasuriya (2016). Living in Java has a positive coefficient value. This shows that cardholders who live in Java have a higher NPL probability than cardholders who live in other areas. This condition is in line with the results from Porto et al. (2017) and Kim et al. (2018), which state that the area of residence affects the probability of NPL.

Table 5. Characteristics of Non-Under/Graduate/Post NPL Cardholders

\begin{tabular}{|c|c|c|}
\hline \multirow{2}{*}{ Non-Under/Graduate/Post } & \multicolumn{2}{|l|}{ NPL } \\
\hline & Number of Cardholder & $\%$ \\
\hline \multicolumn{3}{|l|}{ Occupation } \\
\hline - Self Employed & 520 & 29.56 \\
\hline - Non-Self Employed & 1,239 & 70.44 \\
\hline \multicolumn{3}{|l|}{ Income (Rupiah) } \\
\hline$\leq 10$ million & 1,229 & 69.87 \\
\hline 3 - 5 million & 836 & 68.02 \\
\hline > 5 - 10 million & 393 & 31.98 \\
\hline > 10 million & 530 & 30.13 \\
\hline \multicolumn{3}{|l|}{ Residential Area } \\
\hline Java & 1,631 & 92.72 \\
\hline Non-Java & 128 & 7.28 \\
\hline \multicolumn{3}{|l|}{ Marital Status } \\
\hline Married & 1,054 & 59.92 \\
\hline Single/Widow/Widower & 705 & 40.08 \\
\hline \multicolumn{3}{|l|}{ Home Ownership Status } \\
\hline Own & 619 & 35.19 \\
\hline Not Own & 1,140 & 64.81 \\
\hline TOTAL & 1,759 & \\
\hline
\end{tabular}


The payment to bill ratio (RP) is a negative coefficient, meaning low RP will increase the probability of NPL cardholders. This condition is in line with the results from Stavins (2000), Muthomi (2005), Muchiru (2008), Zhao et al. (2009), Bellotti \& Crook (2013), and Warnakulasuriya (2016). Bill to credit limit ratio (RL) has a positive coefficient, meaning high RL will increase the probability of NPL cardholders. This condition is in line with the results from Kim (2000), Muthomi (2005), Muchiru (2008), Zhao et al. (2009), Nyamongo (2011), and Wang et al. (2014).

Cash Advance (CA) frequency has a negative coefficient, so low CA will increase the probability of NPL cardholders. This condition differs from Muthomi (2005), Muchiru (2008), and Zhao et al. (2009), who all showed that a high CA frequency would increase the probability of NPL. This condition can occur because of differences in cardholder behavior, regulator policies in each country, and credit card provisions in each bank. According to BI regulation No. 17/51/DKSP/2015, the maximum CA limit per day through an ATM is IDR 10 million (magnetic stripe card) and IDR 15 million (chip card). Banks apply a maximum CA limit of $40 \%$ of the credit limit with a minimum nominal limit per CA of IDR 100,000. The maximum percentage of the credit limit related to cash withdrawal transactions means that cardholders who do not pay off their credit card bills will not be able to perform CA if they have reached the maximum limit. Thus, cardholders who pay bills tend to have higher cash advance transaction frequencies than cardholders who do not pay credit card bills.

The number of credit cards has a negative coefficient, so a low number of credit cards will increase the probability of NPL cardholders. This condition is consistent with a study by Bellotti \& Crook (2013). Banks tend not to approve the addition of credit cards to cardholders who make partial payments or have a history of late payments. Therefore, cardholders have a slight chance of getting more credit cards than cardholders who always make total payments.

Figure 5. RP and RL of Non-NPL and NPL Cardholder based on Limit Credit Categories

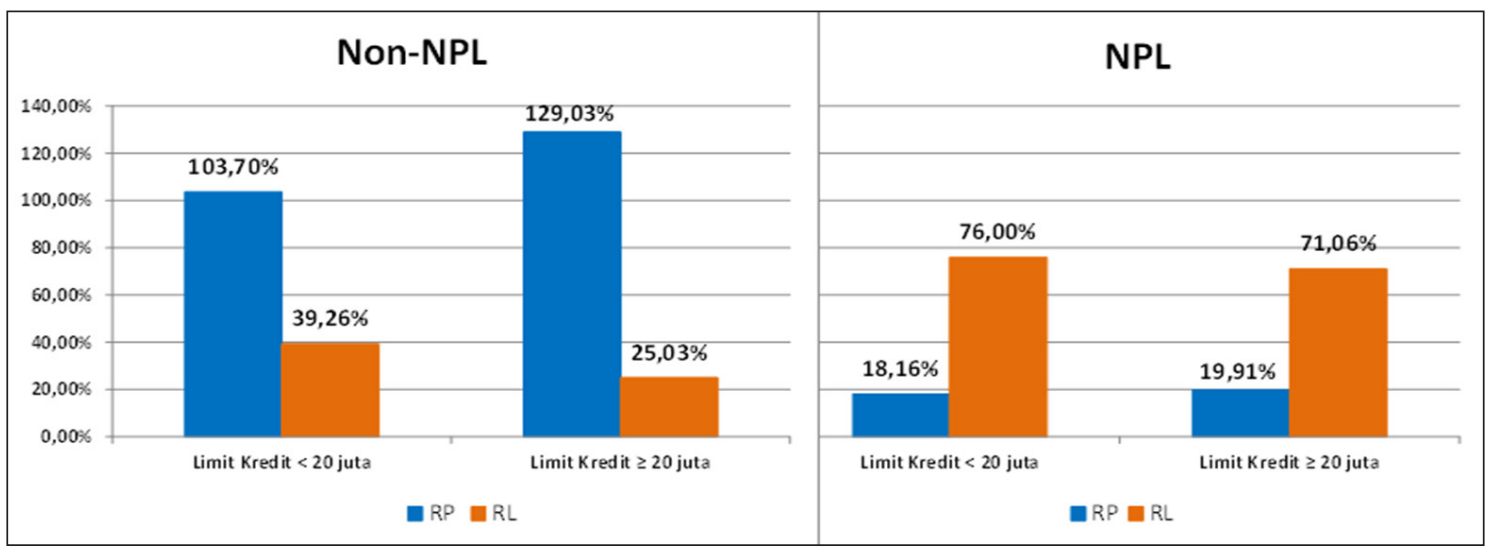

Credit card limit has a negative coefficient, so cardholders with a credit card limit greater than IDR 20 million have a higher NPL probability than cardholders with a lower limit. This result is supported by previous work from Muchiru (2008), Bellotti and 
Crook (2013), and Gui (2019). Banks tend not to approve the addition of a credit limit to cardholders with a low payment to bill (RP) ratio and a high bill to credit limit (RL) ratio. Figure 5 shows that both Non-NPL and NPL cardholders with credit limits less than IDR 20 million have low RP and high RL compared to credit limits over IDR 20 million.

Based on the study result above, there are managerial implications that can be used by banks when making decisions. Banks can use demographic characteristics to increase credit card NPL probabilities to improve current credit card feasibility analysis indicators. In addition, banks need to consider using cardholder behavior indicators in credit scoring. This indicator is necessary because cardholder behavior factors have a higher probability of influencing credit card NPL than demographic factors. The behavior can be identified by several questions added to the credit card application form. Banks can validate the answers of prospective cardholders by confirming with other banks (bank checking) where the prospective cardholder has an existing or prior credit card.

Banks can also control NPL by selecting credit cards to customers (depositors) who do not have credit cards. The criteria for selecting potential customers can use demographic characteristics that significantly affect the credit card NPL based on the results of this study. Specifically, banks can use indicators that increase the probability for non-NPL cardholders. Banks can use SMS, email, or push notifications on Internet banking sites and mobile banking apps to inform selected customers. Interested customers can immediately confirm without filling out a credit card application form because the bank already has the customer's data. This condition will improve customer experiences and satisfaction with the bank. In addition, this mechanism will provide efficiencies (reduce bank operational costs) such as telemarketing fees, telephone costs, and printing costs for credit card application forms.

Behavior scoring reflects each cardholder's risk level based on indicators of demographic characteristics and behavior used. Bank can use demographic characteristics and cardholder behavior that significantly influences the credit card NPL as an indicator of behavior scoring for cardholders. Behavior scoring can be used as an early warning indicator of NPL opportunities from each cardholder so that banks can anticipate activity before the unpaid bills increase. Anticipatory actions that can be taken include reducing the use of credit card limits below 100\%. In addition, banks can also offer installment features to cardholders with low behavior scoring (risk of default) to ease the payment process and maintain good credit cardholder quality.

Furthermore, banks can use behavior scoring to increase credit card portfolios and customer engagement by automatically increasing credit limits for cardholders with high (good) scoring. Behavior scoring can also be used as a reference to approve requests for temporary or permanent credit limit increases and credit card additions. This scoring will speed up the decision on the cardholder's request. In the current era of digitalization, banks can maximize behavior scoring to make decisions on requests for temporary or permanent credit limit increases and the addition of credit cards through mobile banking or internet banking. This action can speed up the process and reduce labor and other operational costs compared to the current credit card processing methods. 
Banks can control credit card NPL through credit card promotions offered to cardholders. Currently, a bank's promotion program is based on the type of credit card and the need of the cardholder to increase the volume of the credit card transaction. Identification of needs can analyze previous cardholder transactions (event-based marketing). However, this promotion process does not consider the demographic characteristics and behavior of cardholders who have a probability of NPL. Therefore, a bank can use both factors when choosing the correct cardholder as a credit card promotion target. Thus, business targets can be achieved, and credit card NPL can also be controlled.

\section{CONCLUSION}

According to the logistic regression model, young cardholders, male, non-under/ graduate/post-education, self-employed, and living in Java all increase probability of cardholder NPL. Cardholder behavior provides a higher likelihood of NPL than demographic characteristics. Cardholder behaviors that increase the likelihood of NPL are a low payment to bill (RP) ratio, high bill to credit limit (RL) ratio, low frequency of cash advance, low number of credit cards, and credit card limits < IDR 20 million. The number of credit cards shows the highest NPL probability.

Based on the results of this study, there are managerial implications that banks can use when making decisions. Demographic characteristics and cardholder behavior that significantly influence credit card NPL can improve the feasibility analysis tools for new cardholders (credit scoring system) and as indicators of behavior scoring systems for existing cardholders. Banks can maximize behavior-scoring systems to automatically increase credit limits for selected cardholders and provide automatic approval of requests to increase credit limits temporarily or permanently. Banks can also control NPL by offering credit cards selectively to existing customers who do not have credit cards and offering selective promotion programs based on demographic characteristics and behavior that significantly affect credit card NPL based on the results of this study. The consumer can add Credit cards through mobile banking and Internet banking.

\section{REFERENCES}

Agarwal, S., Chomsisengphet, S., \& Liu, C. (2011). Consumer Bankruptcy and Default: The Role of Individual Social Capital. Journal of Economic Psychology, 32(4), 632650. https://doi.org/10.1016/j.joep.2010.11.007.

Bank Indonesia. (2012). Peraturan Bank Indonesia Nomor 14/15/PBI/2012 tentang Penilaian Kualitas Aset Bank Umum. Bank Indonesia. Jakarta

Bank Indonesia. (2016). Surat Edaran No. 18/33/DKSP perihal Perubahan Keempat atas Surat Edaran Bank Indonesia Nomor 11/10/DASP tanggal 13 April 2009 perihal Penyelenggaraan Kegiatan Alat Pembayaran dengan Menggunakan Kartu. Bank Indonesia. Jakarta

Bellotti, T., \& Crook, J. (2013). Forecasting and Stress Testing Credit Card Default Using Dynamic Models. International Journal of Forecasting, 29(4), 563-574. https://doi. org/10.1016/j.ijforecast.2013.04.003. 
Chin, K.Y., Yi, W.C., Kwan, C.L., \& Si, C.M. (2017). An Empirical Investigation on Credit Card Repayment Pattern of Academicians in Malaysia. The International Journal of Banking and Finance, 13(2), 21-42.

Firdaus, M., Harmini, \& Farid, M. A. (2011). Aplikasi Metode Kuantitatif untuk Manajemen dan Bisnis. IPB Press. Bogor.

Gui, L. (2019). Application of Machine Learning Algorithms in Predicting Credit Card Default Payment. (Unpublished Thesis). Universitas of California.

Halperin, M., Blackwelder, W. C., \& Verter, J. I. (1971). Estimation of the Multivariate Logistic Risk Function: A Comparison of the Discriminant Function and Maximum Likelihood Approaches. Journal of Chronic Diseases, 24(2-3), 125-158. https://doi. org/10.1016/0021-9681(71)90106-8.

Huang, S. (2018). A Research on The Default Risk of Credit Card Client in Thailand. UMT Poly Journal, 16(1), 254-264.

Kiarie, F. K., Nzuki, D. M., \& Gichuhi, A. W. (2015). Influence of Socio-Demographic Determinants on Credit Card Default Risk in Commercial Bank in Kenya. International Journal of Science and Research, 4(5), 1611-1615.

Kim, H., Cho, H., \& Ryu, D. (2018). An Empirical Study on Credit Card Loan Delinquency. Economic Systems, 42(3), 437-449. https://doi.org/10.1016/j.ecosys. 2017.11.003.

Kim, T. (2000). Investigation of U.S. Credit Card Market Using Original Survey Data. (Unpublished Dissertation). The Ohio State University.

Kuncoro, M. (2005). Metode Penelitian Bisnis. Erlangga. Jakarta.

Leow, M., \& Crook, J. (2014). Intensity Models and Transition Probabilities for Credit Card Loan Delinquencies. European Journal of Operational Research, 236(2), 685-694.

Li, Y., Li, Y., \& Li, Y. (2019). What Factors are Influencing Credit Card Customer's Default Behavior in China? A study based on survival analysis. Physica A: Statistical Mechanics and Its Applications, 526, 120861. https://doi.org/10.1016/j.physa.2019. 04.097.

Muchiru, S. (2008). An Investigation into The Determinants of Credit Card Default in Kenya (A Case of The Imperial Bank Limited). (Unpublished Thesis). University of Nairobi.

Muhmin, A. G. A., \& Umar, Y.A. (2007). Credit Ownership and Usage Behaviour in Saudi Arabia: The Impact of Demographic and Attitudes toward Debt. Journal of Financial Services Marketing, 12, 219-234. https://doi.org/10.1057/palgrave.fsm.4760074.

Muthomi, J. (2005). Application of Multiple Discriminant Analysis Credit Scoring Model, For Credit Card Consumer - The Case of BarclayCard Kenya. (Unpublished Dissertation). University of Nairobi.

Norvilitis, J. M., \& Maria, S. P. (2002). Credit Card Debt on College Campuses: Causes, Consequences and Solutions. College Student Journal, 36(3), 356-363.

Nyamongo, M. C. (2011). The Relationship Between Credit Default Risk and Cardholder Characteristics, Credit Card Characteristics, Behavioral Scoring Process Among Commercial Bank in Kenya. (Unpublished Thesis). University of Nairobi. 
Porto, N., Huang, Y., \& Xiao, J. J. (2017). Credit Card Adoption and Usage in China: Urban-Rural Comparisons. The Singapore Economic Review, 64(1), 41-56. https:// doi.org/10.1142/S021759081743010X.

Press, S. J., \& Wilson, S. (1978). Choosing Between Logistic Regression and Discriminant Analysis. Journal of the American Statistical Association, 73(364), 699-705. https:// doi.org/2286261.

Sayono, J. A., Sumarwan, U., Achsani, N. A., \& Hartoyo. (2009). Analisis Faktor-Faktor yang Memengaruhi Kepemilikan, Penggunaan, Pembayaran, dan Peluang Terjadinya Gagal Bayar dalam Bisnis Kartu Kredit. Jurnal Ekonomi \& Bisnis, 3(1), 61-80.

Stavins, J. (2000). Credit Card Borrowing, Deliquency, and Pesonal Bankruptcy. New England Economic Review, July/August, 16-30.

Wang, L., Lu, W., \& Malhotra, N. K. (2011). Demographics, Attitude, Personality and Credit Card Features Correlate with Credit Card Debt: A View from China. Journal of Economic Psychology, 32(1), 179-193. https://doi.org/10.1016/j.joep.2010.11.006.

Wang, L., Malhotra, N. K., \& Lu, W. (2014). Determinants of Credit Card Debt: Differentiating Between Revolving Credit Debt and Petty Installment Loan in China. Journal of Consumer Behaviour, 13(4), 294-302. https://doi.org/10.1002/cb.1474.

Warnakulasuriya, M. N. (2016). Factor Affecting Non-Performing Portofolio of Credit Card Based Personal Financing: Case of Sampath and Hatton National Bank in Colombo District. (Unpublished Thesis). University of Sri Jayewardenepura.

Wilson, S. (2007). A Causal Framework for Credit Default Theory. Australian Prudential Regulation Authority. Australia

Zhao, Y., Zhao, Y., \& Song, I. (2009). Predicting New Customers' Risk Type in The Credit Card Market. Journal of Marketing Research, 46(4), 506-517. https://doi. org/10.1509/jmkr.46.4.506. 